\title{
Feeding guild composition of a macrobenthic subtidal community along a depth gradient
}

\author{
MARINA DOLBETH, HELIANA TEIXEIRA, JOÃO CARLOS MARQUES \\ and MIGUEL ÂNGELO PARDAL \\ Institute of Marine Research (IMAR), c/o Department of Zoology, University of Coimbra, 3004-517 Coimbra, Portugal. \\ E-mail,mdolbeth@ci.uc.pt
}

SUMMARY: The feeding guild composition of a macrobenthic community from southern Portugal was studied along a depth gradient $(1.3$ to $32 \mathrm{~m}$ ). This gradient comprised shallow areas with severe physical stress and deeper areas with no significant hydrodynamic impact at the seafloor. The main goal was to determine the influence of the spatial and temporal differences of the hydrodynamic impact at the seafloor on the feeding guild composition of the macrobenthic community. The feeding guild composition changed gradually with depth, which reflects the differences in the hydrodynamics impact at the seafloor. Herbivores and sand-lickers dominated at the shallowest depths with fine sands, which correlated with higher levels of primary production. Scavengers were also distributed in the shallow areas, which was associated with the lower predation impact. Suspension feeders, in accordance with their physiological requirements, were distributed in coarser sands subjected to a physical impact. Carnivores, surface deposit feeders and sub-surface deposit feeders were distributed mainly below $8 \mathrm{~m}$ depth, where there was no significant impact from the wave climate. Carnivores were associated with coarser sands and were mainly small polychaetes and nemerteans. Sub-surface and surface deposit feeders were more abundant in the deepest areas of the depth gradient with fine sands and mud deposits with higher organic content. However, surface deposit feeders also occurred at shallower depths. Some seasonal differences related to disturbance impacts were found in the numerical dominance of the feeding guilds.

Keywords: macrobenthic community, feeding guilds, depth gradient, hydrodynamics.

RESUMEN: COMPOSICIÓN DE GRUPOS TRÓFICOS FUNCIONALES EN UNA COMUNIDAD MACROBENTÓNICA SUBMAREAL A LO LARGO DE UN GRADIENTE DE PROFUNDIDAD. - Se han estudiado las categorías tróficas de una comunidad macrobentónica en el sur de Portugal, a lo largo de un gradiente de profundidad (de $1.3 \mathrm{~m}$ a $32 \mathrm{~m}$ ). Este gradiente incluía áreas someras (poco profundas) con un estrés físico severo y áreas más profundas sin impacto hidrodinámico significativo a nivel del fondo marino. El objetivo principal fue determinar la influencia de las diferencias espaciales y temporales del impacto hidrodinámico en el fondo marino sobre la composición de las categorías tróficas de la comunidad macrobentónica. La composición de estas categorías tróficas cambió gradualmente con la profundidad, reflejando las diferencias del impacto hidrodinámico en el lecho marino. Las profundidades más someras, compuestas por arenas finas, estaban dominadas por anfípodos herbívoros y raspadores de arenas, correspondiéndose con elevados niveles de producción primaria. También había en estas áreas someras carnívoros/necrófagos asociados a un menor impacto de predación. Los suspensívoros, fundamentalmente bivalvos, predominaron en zonas con arenas más gruesas y mayor hidrodinamismo, de acuerdo con sus necesidades fisiológicas. Por debajo de los $8 \mathrm{~m}$ de profundidad y en zonas donde no se produce impacto del oleaje, dominaban carnívoros, detritívoros de fondo y de sub-fondo. Los carnívoros, asociados a arenas más gruesas, eran principalmente pequeños poliquetos y nemertinos. Los detritívoros de fondo y sub-fondo eran más abundantes en las zonas más profundas del gradiente, donde aparecían arenas finas y depósitos de limo con elevados contenidos en materia orgánica. Sin embargo, también se encontraron detritívoros de fondo en profundidades menores. Se encontraron algunas diferencias en la dominancia numérica de la estructura trófica a lo largo del año, lo que puede estar relacionado con impactos de incidentes en la zona.

Palabras clave: comunidad macrobentónica, grupos tróficos funcionales, gradiente de profundidad, hidrodinámica. 


\section{INTRODUCTION}

In marine soft sediments, the hydrodynamics can be considered as a source of natural disturbance that structures species' distributions (Rosenberg, 1995; Levin and DiBacco, 1995; Roth and Wilson, 1998; Hewitt et al., 2003). Sediment characteristics are, to a large extent, the direct result of near-bed flow conditions, which influence grain size, sedimentary organic matter content, pore-water chemistry, microbial content, larval supply (Snelgrove and Butman, 1994) and food availability (Morin et al., 1985; Incera et al., 2003). These variables can directly or indirectly influence the benthic community's distribution (Snelgrove and Butman, 1994) and functioning. Food availability in the seafloor sediments can change according to the hydrodynamics and morphodynamics (Levin and DiBacco, 1995; Roth and Wilson, 1998; Arruda et al., 2003; Hewitt et al., 2003; Wieking and Kröncke, 2005) and due to man-induced disturbances (Sardá et al., 2000; Chícharo et al., 2002a, b). Differences can be found in the feeding guild composition in relation to the food quality, quantity and the environmental regime (Morin et al., 1985).

A previous study on the macrobenthic community was performed in southern Portugal (Dolbeth et al., 2007), along a depth continuum (1.3 $\mathrm{m}$ to $32 \mathrm{~m}$ depth), which comprised areas subjected to a hydrodynamic impact on the seafloor and areas below the depth of closure, i.e. with limited sediment transport due to wave action (Nicholls et al., 1998). Both physical and biological environments were studied spatially and over time. Spatial differences in the benthic community's composition were detected in relation to the differences in the hydrodynamics and morphodynamics (Dolbeth et al., 2007). Community patterns also changed due to the occurrence of storms, which had a larger impact than the low seasonality (Dolbeth et al., 2007). One of the remaining questions is how the differences in the physical environment affect the functioning of the benthic subtidal community. The present study aims to: 1) characterise the feeding guild composition of a benthic community along a depth gradient ( 1 to $32 \mathrm{~m}$ depth); 2) determine the relationships between the feeding guild composition and environmental parameters; and 3) determine how the spatial and temporal differences of the hydrodynamic impact at the sea bottom changed the feeding guild composition. General considerations on the structure of the macrobenthic community are also presented.

\section{MATERIAL AND METHODS}

\section{Study site}

The study was conducted at Ancão Peninsula $\left(37^{\circ} 00^{\prime} \mathrm{N}, 8^{\circ} 00^{\prime} \mathrm{W}\right)$, the western limit of the Ria Formosa (Algarve, Portugal) (Dolbeth et al., 2006, 2007). Tides are semi-diurnal with a mean tidal range of about $2.5 \mathrm{~m}$ and a maximum of about $3.5 \mathrm{~m}$. The study area is directly exposed to wave energy, as the dominant direction is W-SW. The wave energy can be considered moderate with an average annual significant wave height (Hs) of $0.92 \mathrm{~m}$ (Costa et al., 2001). Storm conditions ( $\mathrm{Hs}>3 \mathrm{~m}$ ) do not exceed $2 \%$ of the wave records; waves $>5 \mathrm{~m}$ represented about $0.2 \%$ of the records (Costa et al., 2001). The beach can be classified as Low Tide Terrace + Rip and considered as intermediate to reflective (Ferreira et al., 1997).

Surveys were conducted between 2001 and 2002 and were strongly limited by the wave climate; therefore, only 7 samplings were possible: June 01 (late spring), September 01 (late summer), February 02 (winter), May 02, June 02 (late spring), July 02 (summer) and October 02 (autumn). During this period, 4 storms occurred with a maximum significant height of almost $5 \mathrm{~m}$ in the period of mid-September 01 to mid-February 02 , and were therefore classified as near extreme storms according to the regional wave regime (Dolbeth et al., 2007). Three other storms (maximum significant wave height $=4$ $\mathrm{m})$ occurred in the period from mid-February 02 to mid-May 02, and a single storm with smaller wave energy (maximum significant wave height $=3.3 \mathrm{~m}$ ) and duration ( 3 hours maximum) occurred from midJuly 02 to the end October 02 . The depth of closure, below which limited sediment transport due to wave action is expected (Nicholls et al., 1998), varied from a maximum value of $6.6 \mathrm{~m}$ to $10 \mathrm{~m}$ depth from mid-September 01 to mid-May 02, to the minimum values of $2 \mathrm{~m}$ to $3 \mathrm{~m}$ depth in July 01 until mid-September 01, and mid-May 02 until the end of October 02 (Dolbeth et al., 2007). Detailed information on the wave climate and morphological parameters is available in Dolbeth et al. (2007).

\section{Sampling procedures}

Samples were taken along a depth gradient towards the eastern end of the Ancão Peninsula. 14 stations in this area were sampled along a transect 
perpendicular to the coastline (from $37^{\circ} 00^{\prime} \mathrm{N}$, $8^{\circ} 00^{\prime} \mathrm{W}$ to $\left.36^{\circ} 58^{\prime} \mathrm{N}, 8^{\circ} 02^{\prime} \mathrm{W}\right)$ : at $100,200,300,400$, 500, 600, 800, 1000, 1400, 1800, 2400, 3000, 4000, $5000 \mathrm{~m}$ from the coastline. These stations comprise a depth gradient ranging from $1.6 \pm 0.3 \mathrm{~m}$ to 31.8 $\pm 0.2 \mathrm{~m}$ depth (tidal corrected depth). In June 01, no samples were taken at the $5000 \mathrm{~m}$ station and in February 02 sampling was carried out at $4500 \mathrm{~m}$ due to logistic constraints.

Biological material was collected using a Ponar grab $\left(248 \mathrm{~cm}^{2}\right)$, which was dropped from a research vessel (7 m length). Each grab had an estimated minimum depth of penetration of $10 \mathrm{~cm}$. In general, four grabs of the sediment and biological material were taken at each sampling station (samples washed in $500 \mu \mathrm{m}$ mesh bag). In June 01, February 02 and June 02, one extra grab was collected for sediment analysis (at each of the sampling points). 383 samples of macrobenthic fauna and 40 sediment samples were taken. In the laboratory, biological material was sorted, identified to the lowest possible taxon and counted. The sediment samples were analysed to determine grain size. The sediment was first combusted $\left(8 \mathrm{~h}\right.$, at $\left.450^{\circ} \mathrm{C}\right)$, and the grained material sieved thorough successively smaller sieves $(0.063 \mathrm{~mm}, 0.090 \mathrm{~mm}, 0.125 \mathrm{~mm}$, and so on until $>2 \mathrm{~mm}$ ), then classified according to Shepard (1954). It was assumed that sediment characteristics would present major changes within each 6 month period, and that major changes would occur from the periods moving from higher to calmer wave climate impact and vice versa (from June 01 to February 02 and from February 02 to June 02).

The water present in the samples from the $\mathrm{Po}$ nar grab, with the biological material (from the sea bottom), was collected at each of the sampling stations and for each sampling date. Temperature, salinity, dissolved oxygen and $\mathrm{pH}$ of this water were measured in situ and in the laboratory, the water was analysed for dissolved nutrients and chlorophyll $a$. Ammonia $\left(\mathrm{NH}_{3}-\mathrm{N}\right)$ and phosphate $\left(\mathrm{PO}_{4}-\mathrm{P}\right)$ concentration were determined following the methods described in Limnologisk Metodik (1992) and nitrate $\left(\mathrm{NO}_{3}-\mathrm{N}\right)$, and nitrite $\left(\mathrm{NO}_{2}-\mathrm{N}\right)$ according to the methods in Strickland and Parsons (1972). The chlorophyll $a(\mathrm{Chl} a)$ determinations were performed by filtering 1.51 of water through Whatman GF/C glass-fibre filters, followed by acetone extraction and colorimetric reading according to Parsons et al. (1985).

\section{Macrobenthic feeding guild assignments}

Each taxon was assigned to a feeding guild according to its food type. The feeding guilds used in this study were carnivores $(\mathrm{C})$, herbivores $(\mathrm{H})$ and detritivores; this last group was divided into sandlickers (SL), scavengers (S), subsurface-deposit feeders (SSDF), surface-deposit feeders (SDF) and suspension feeders (SF), according to the following literature: Fauchald and Jumars, 1979; Gaston, 1987; Sprung, 1994; Oug et al., 1998; Mancinelli et al., 1998; Wieking and Kröncke, 2003, 2005, MarLin species database - http://www.marlin.ac.uk/sah/species_information.php. Some species could not be confidently classified using the available schemes and these were grouped as unknown (U).

\section{Statistical analysis}

The composition and structure of the macrobenthic community's feeding guild were investigated using multivariate techniques. For comparison purposes, a first analysis was made of both the species and the feeding guild composition along the depth gradient. The similarity between the species densities and the feeding guild densities for each sampling station (each depth of the gradient) and all sampling dates was tested with the ANOSIM procedure. Pairwise tests were analysed to determine the presence or absence of different faunal and feeding guild groups along the gradient (i.e. to test whether different stations had similar fauna and feeding guilds). Similarity relationships between the species and the feeding guild densities (7 sampling dates, 13 sampling stations) were determined with the Bray-Curtis coefficient. The species densities data was squareroot-transformed; the feeding guild group data was not transformed. A non-metric multidimensional scaling (MDS) analysis was also performed. The feeding guilds that most contributed to the similarity between sampling stations/depths were identified with the Similarity Percentages (SIMPER) analysis. This analysis was only performed with the feeding guilds. The SIMPER analysis for the species composition is reported in Dolbeth et al. (2007). These analyses were performed with the PRIMER $\vee 6.0$ software.

A redundancy analysis (RDA) was performed to evaluate the relationships between different feeding guild densities and the environmental variables. All environmental variables were used in a first analysis 
TABLE 1. - Temperature, salinity, $\mathrm{pH}$, nitrite $\left(\mathrm{NO}_{2}-\mathrm{N}\right)$ and nitrate $\left(\mathrm{NO}_{3}-\mathrm{N}\right)$ means \pm standard deviation for the entire depth gradient, for the main seasons: spring/summer 01 and 02 , winter 02 and autumn 02 .

\begin{tabular}{|c|c|c|c|c|}
\hline & Spring/Summer 01 & Winter 02 & Spring/Summer 02 & Autumn 02 \\
\hline Temperature $\left({ }^{\circ} \mathrm{C}\right)$ & $19.5 \pm 0.34$ & $15.5 \pm 0.34$ & $18.6 \pm 1.02$ & $19.1 \pm 0.35$ \\
\hline Salinity & $34.6 \pm 0.08$ & $34.2 \pm 0.07$ & $36.0 \pm 0.46$ & $36.5 \pm 0.07$ \\
\hline $\mathrm{pH}$ & $7.9 \pm 0.06$ & $8.3 \pm 0.01$ & $8.2 \pm 0.05$ & $8.3 \pm 0.03$ \\
\hline $\mathrm{NO}_{2}-\mathrm{N}(\mu \mathrm{gL}-1)$ & $2.4 \pm 0.56$ & $0.6 \pm 0.31$ & $2.3 \pm 1.32$ & $2.3 \pm 1.17$ \\
\hline $\mathrm{NO}_{3}-\mathrm{N}\left(\mu \mathrm{gL}^{-1}\right)$ & $9.4 \pm 3.62$ & $12.5 \pm 5.78$ & $23.6 \pm 16.59$ & $35.1 \pm 18.86$ \\
\hline
\end{tabular}

and their significance was tested with the forward selection procedure. A second RDA was performed with only the significant environmental variables. The RDA was chosen because the linear response of the feeding guild densities data was detected with the Detrended Correspondence Analysis (DCA). These analyses were performed with the CANOCO v 4.5 software.

\section{RESULTS}

\section{Seawater and sediment analysis}

Stable values of salinity and $\mathrm{pH}$ were observed throughout the depth gradient and seasons, whereas temperature showed seasonal variations in accordance with temperate systems (Table 1). The highest variations in nutrient concentrations along the depth gradient and during the different seasons were found for ammonia $\left(\mathrm{NH}_{3}-\mathrm{N}\right)$ and phosphate $\left(\mathrm{PO}_{4}-\mathrm{P}\right)$ (Fig. 1). $\mathrm{PO}_{4}-\mathrm{P}$ concentration increased with decreasing depth. The values observed in the winter ranged between 10 and $20 \mu \mathrm{gL}^{-1}$, and in spring/summer 01 and autumn 02 between 20 and $50 \mathrm{\mu L}^{-1}$ (Fig. 1). No clear pattern was observed for $\mathrm{NH}_{3}-\mathrm{N}$ along the depth gradient; however, the range of values for spring/summer 02 and autumn 02 at the shallowest depths was between 40 and $70 \mu \mathrm{gL}^{-1}$ and lower than $40 \mu \mathrm{gL}^{-1}$ in the following depths (Fig. 1). The mean values per season obtained for chlorophyll $a$ were $2 \mu \mathrm{gL}^{-1}$ for winter, $5 \mu \mathrm{gL}^{-1}$ for spring/summer 01 , and $9 \mu \mathrm{gL}^{-1}$ for both spring/summer 02 and autumn 02 (Fig. 1). For these last seasons, chlorophyll $a$ concentrations at shallower depths were higher than in deeper areas, from $22 \mathrm{~m}$ depth (Fig. 1).

Sediment texture showed clear zonation with depth. Fine to very fine sands were observed until $4 \mathrm{~m}$ depth in June 01 and February 02, and extended down to $7 \mathrm{~m}$ in June 02 (Fig. 2). In the deeper areas $(>4 \mathrm{~m}$ in June 01 and February 02
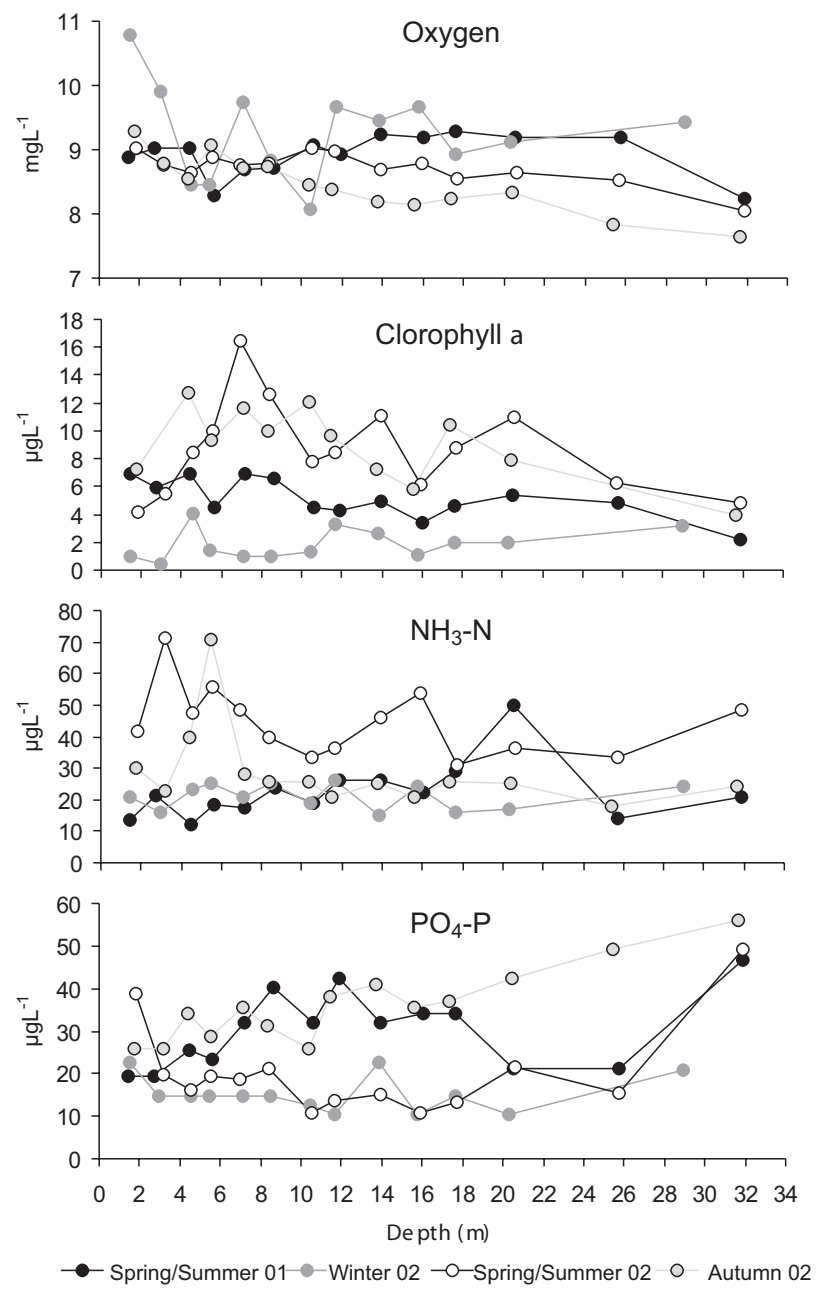

FIG. 1. - Variation of oxygen, chlorophyll $a$, ammonia $\left(\mathrm{NH}_{3}-\mathrm{N}\right)$ and phosphates $\left(\mathrm{PO}_{4}-\mathrm{P}\right)$ along the depth gradient, for the main seasons: spring/summer 01 and 02 , winter 02 and autumn 02 .

and $>10 \mathrm{~m}$ in June 02 ) coarser sands dominated down to at least $20 \mathrm{~m}$ (Fig. 2). Relict and biogenic sediments composed of empty shells mixed with coarse sands and gravel appeared below $25 \mathrm{~m}$ depth. Fine sands were also detected in positions near rocky outcrops (rocky outcrops located at $25.6 \mathrm{~m}$ depth, not shown in Fig. 2) together with the biogenic sediments (sampling station 5000, June 02) (Fig. 2). 


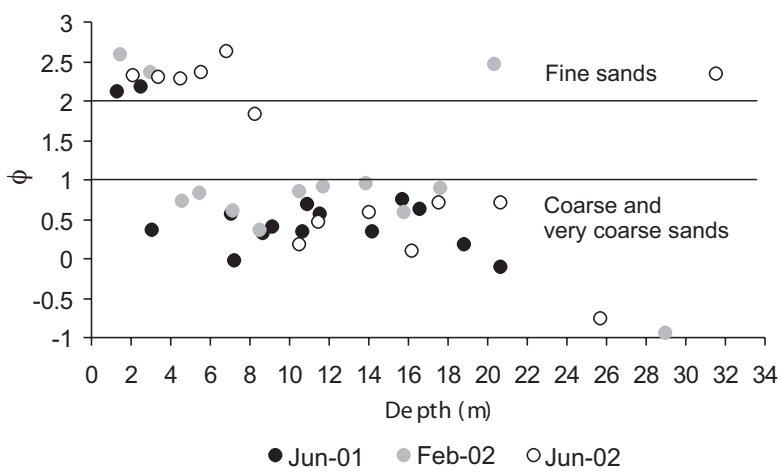

FIG. 2. - Sediment texture (mean grain size, in $\phi\left[\phi=\log _{2}(\mathrm{~mm})\right]$ ) along the depth gradient. Classification, $\phi[-1$ to 0$]$ : very coarse sands; $\phi[0$ to 1$]$ : coarse sands; $\phi[1$ to 2$]$ : median sands; $\phi$ [2 to 3$]$ : fine sands.

\section{Macrobenthic community}

\section{Taxonomic considerations}

345 taxa were identified during the study period. Species were assigned to the main taxa: Annelida, Crustacea, Mollusca, Echinodermata and a group (others) comprised of Phascolion strombus (Sipuncula), Branchiostoma lanceolatum (Chordata) and Nemertea (for which species were not identified) (Fig. 3). Nematoda, Platyhelmintha, Copepoda (meiofauna components), Cnidaria, Porifera and Bryozoa (colonial species for which density was difficult to assess) were also found in the samples, but were not used in the subsequent analysis.

Annelida had the highest density values when compared to the other taxa (Fig. 3). The highest density of Annelida was observed between $8 \mathrm{~m}$ and $26 \mathrm{~m}$ depth (Fig. 3). Pisione remota, Goniada galaica and Caulleriella bioculata were the most abundant species (Table 2). The highest densities of Crustacea were found mainly at the shallowest depths (Fig. 3), where Diogenes pugilator, Bathyporeia spp. and Siphonoecetes sp. attained high densities (Table 2). The amphipod Cheirocratus sp. also attained high densities, especially from 8 to $26 \mathrm{~m}$ depth (Table 2). At intermediate depths, below $26 \mathrm{~m}$, Crustacea also attained high densities, especially in autumn 02 ( $>900$ ind $\mathrm{m}^{-2}$, Fig. 3). Mollusca showed the highest density values between $4 \mathrm{~m}$ and $8 \mathrm{~m}$ depth (Fig. 3), and Tellina spp., Spisula solida and Donax spp. were the main species (Table 2). Corbulla gibba was abundant only at $32 \mathrm{~m}$. The group 'others' was abundant mainly between $8 \mathrm{~m}$ and 26 m (Fig. 3), and Phascolion strombus, Nemertea and Branchiostoma lanceolatum were the most abundant species (Table 2). Echinodermata had the lowest density values (Fig. 3). Along the depth gradient, this

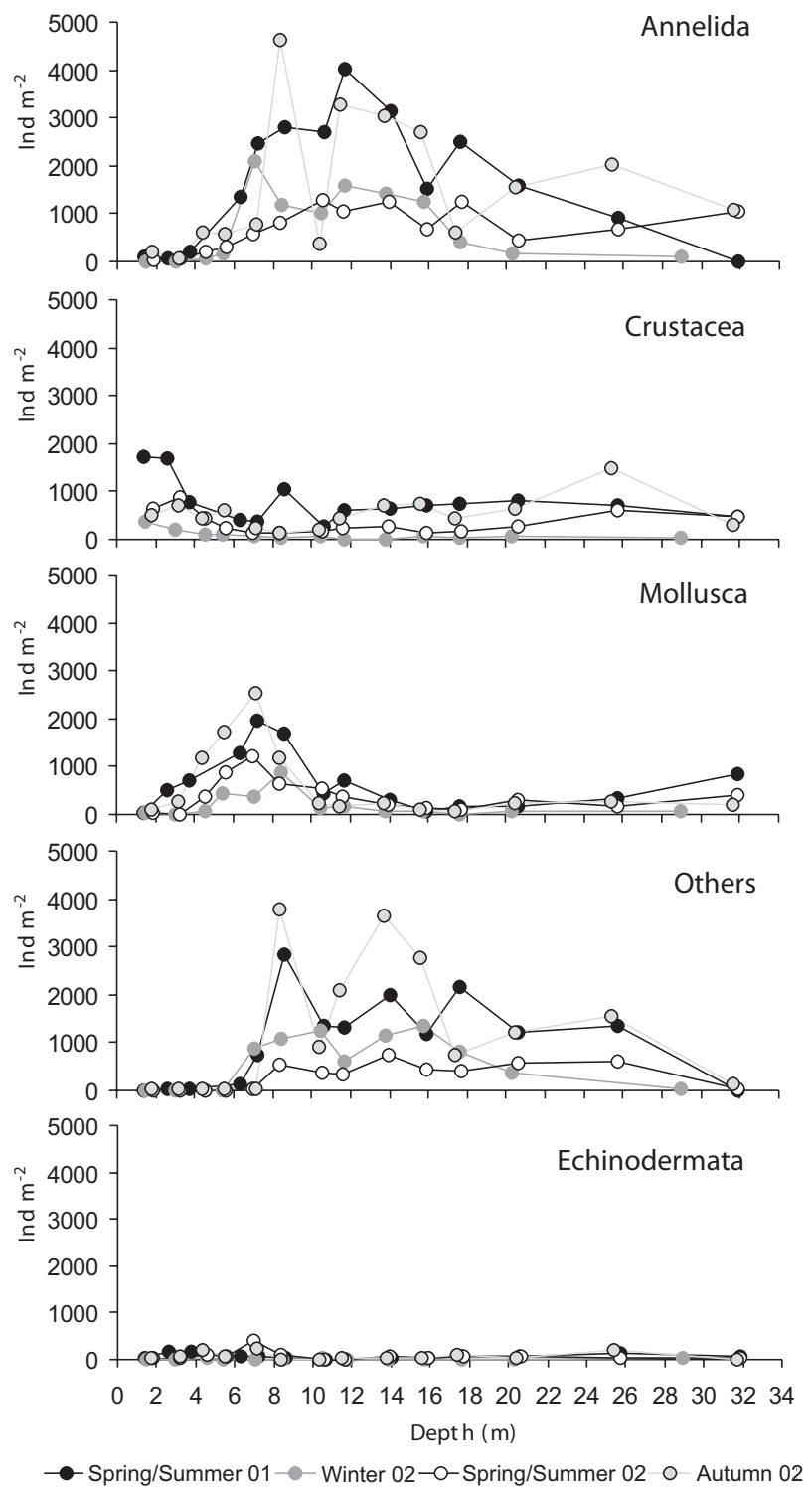

FIG. 3. - Density variation of the main taxa along the depth gradient, for the main seasons: spring/summer 01 and 02 , winter 02 and autumn 02. Others is composed of Nemertea, Phascolion strombus, Branchiostoma lanceolatum.

group was most abundant between 4 and $8 \mathrm{~m}$ and at $26 \mathrm{~m}$ depth (Fig. 3), and Ophiocentrus branchiatus was the numerically dominant species.

The mean density values of the entire community for the whole gradient were 4363 ind $\mathrm{m}^{-2}$ for spring/ summer 01,1588 ind $\mathrm{m}^{-2}$ for winter, 1932 ind $\mathrm{m}^{-2}$ for spring/summer 02 and 3974 ind $\mathrm{m}^{-2}$ for autumn.

\section{Feeding guild compositions}

Carnivores (C) were numerically the most abundant feeding guild in spring and winter (Fig. 4). In these seasons, suspension feeders (SF) and surface- 
TABLE 2. - The most abundant species in the macrobenthic community per feeding guild. The depth distribution and *minimum and maximum mean density ( \pm standard deviation) are indicated for the considered depth distribution.

\begin{tabular}{|c|c|c|c|c|}
\hline Feeding guild & Main group & Most abundant species & $\begin{array}{l}\text { Distribution on the } \\
\text { depth gradient }\end{array}$ & $\begin{array}{l}\text { Mean density* } \\
\quad\left(\text { Ind } \mathrm{m}^{-2}\right)\end{array}$ \\
\hline Carnivores & $\begin{array}{l}\text { Annelida } \\
\text { Annelida } \\
\text { Annelida } \\
\text { Crustacea } \\
\text { Others }\end{array}$ & $\begin{array}{l}\text { Nephtys cirrosa } \\
\text { Pisione remota } \\
\text { Goniada galaica } \\
\text { Harpinia antennaria } \\
\text { Nemertea }\end{array}$ & $\begin{array}{l}4-21 \mathrm{~m} \\
8-26 \mathrm{~m} \\
8-26 \mathrm{~m} \\
32 \mathrm{~m} \\
8-26 \mathrm{~m}\end{array}$ & $\begin{array}{c}15 \pm 16-56 \pm 48 \\
109 \pm 205-921 \pm 868 \\
25 \pm 35-307 \pm 342 \\
0-139 \\
22 \pm 30-464 \pm 264\end{array}$ \\
\hline Carnivore/Scavenger & Crustacea & Diogenes pugilator & $1-7 \mathrm{~m}$ & $73 \pm 42-479 \pm 486$ \\
\hline Sand-lickers & Crustacea & Bathyporeia spp. & $1-3 m$ & $31-1068 \pm 494$ \\
\hline \multirow[t]{2}{*}{ Sub-surface deposit feeders } & $\begin{array}{l}\text { Annelida } \\
\text { Annelida } \\
\text { Mollusca }\end{array}$ & $\begin{array}{l}\text { Mediomastus sp. } \\
\text { Saccocirrus papillocercus } \\
\text { Caecum sp. }\end{array}$ & $\begin{array}{l}6-26 \mathrm{~m} \\
7-11 \mathrm{~m} \\
8-26 \mathrm{~m}\end{array}$ & $\begin{array}{c}7 \pm 11-100 \pm 113 \\
7 \pm 12-646 \pm 478 \\
48 \pm 40-167 \pm 173\end{array}$ \\
\hline & Others & Phascolion strombus & $11-26 \mathrm{~m}$ & $26 \pm 26-335 \pm 384$ \\
\hline Surface deposit feeders & Annelida & Caulleriella bioculata & $8-18 \mathrm{~m}$ & $33 \pm 29-771 \pm 494$ \\
\hline Surface deposit feeders/Herbivores & $\begin{array}{l}\text { Crustacea } \\
\text { Mollusca } \\
\text { Crustacea }\end{array}$ & $\begin{array}{l}\text { Cheirocratus sp. } \\
\text { Corbulla gibba } \\
\text { Siphonoecetes sp. }\end{array}$ & $\begin{array}{c}8-26 \mathrm{~m} \\
32 \mathrm{~m} \\
-2 \mathrm{~m} \text { (occasionally at } 26 \mathrm{~m} \text { ) }\end{array}$ & $\begin{array}{c}0-215 \pm 127 \\
0-250 \\
21-5927\end{array}$ \\
\hline $\begin{array}{l}\text { Surface deposit feeders/ } \\
\text { Suspension feeders }\end{array}$ & $\begin{array}{l}\text { Annelida } \\
\text { Annelida }\end{array}$ & $\begin{array}{l}\text { Prionospio caspersi } \\
\text { Prionospio cirrifera }\end{array}$ & $\begin{array}{c}4-7 \mathrm{~m} \\
32 \mathrm{~m}\end{array}$ & $\begin{array}{c}0-260 \pm 42 \\
14-94\end{array}$ \\
\hline Suspension feeders & $\begin{array}{l}\text { Mollusca } \\
\text { Mollusca } \\
\text { Mollusca } \\
\text { Mollusca } \\
\text { Others }\end{array}$ & $\begin{array}{l}\text { Tellina spp. } \\
\text { Donax spp. } \\
\text { Spisula solida } \\
\text { Calyptraea chinensis } \\
\text { Branchiostoma lanceolatum }\end{array}$ & $\begin{array}{c}4-8 \mathrm{~m} \\
4-8 \mathrm{~m} \\
7-12 \mathrm{~m} \\
32 \mathrm{~m} \\
8-26 \mathrm{~m}\end{array}$ & $\begin{array}{c}7 \pm 12-486 \pm 546 \\
3 \pm 6-350 \pm 443 \\
242 \pm 339-583 \pm 325 \\
0-208 \\
40 \pm 189-648 \pm 209\end{array}$ \\
\hline
\end{tabular}

deposit feeders (SDF) were the second most abundant feeding guilds. For late summer 01 , the density of C, SF and SDF within the total community density was similar $(25 \%, 23 \%$ and $25 \%$ respectively), while in early summer 02, the SF and SDF had higher densities than $\mathrm{C}$ (Fig. 4). For autumn 02, the density of $\mathrm{C}$ and SF was similar (33\% and 34\% respectively).

Along the depth gradient, $\mathrm{C}$ were more abundant from $7 \mathrm{~m}$ to $21 \mathrm{~m}$ depth (Fig. 4), which covered the depth distribution of the most abundant annelids and nemerteans (Table 2). SF density was higher between $4 \mathrm{~m}$ and $10 \mathrm{~m}$ depth, which corresponded to several bivalves (Table 2). Further offshore, SF were also abundant, especially in autumn 02 (Fig. 4), mainly due to $B$. lanceolatum density (Table 2). SDF occurred throughout the whole depth gradient, with no clear depth related dominance pattern (Fig. 4). In the summer, higher densities were obtained at the shallowest depths (Fig. 4) due to Siphonoecetes sp. (Table 2). SSDF achieved higher densities in deeper areas, mainly from $8 \mathrm{~m}$ deep seawards (Fig. 4), generally due to Saccocirrus papillocercus, Caecum sp. and $P$. strombus (Table 2). $\mathrm{H}, \mathrm{S}$ and SL were the least abundant in the community and mainly occurred at shallower depths (Fig. 4) due to D. pugilator, which can behave as either a $\mathrm{H}$ or S, and Siphonoecetes sp., which can behave as a $\mathrm{H}$ or SDF, and to the SL Bathyporeia spp. (Table 2). In the early summer, high densities of $\mathrm{H}$ were detected at $2 \mathrm{~m}$ depth (Fig. 4) due to the high density of Siphonoecetes sp. (5927 ind $\mathrm{m}^{-2}$ ) (Table 2).

\section{Spatial differences}

The ANOSIM for both the species and feeding guild densities showed significant differences for the samples along the depth gradient $(1 \mathrm{~m}$ to $32 \mathrm{~m}$ depth). However, differences were clearer with the species composition $(\mathrm{R}=0.603, \mathrm{p}=0.001)$, because for the feeding guild composition the associated $\mathrm{R}$ value was lower $(R=0.147, p=0.001)$. After detecting significant differences with ANOSIM, pairwise tests were used to determine whether there were groups of similar samples along the depth gradient. Different samples clustered for the species composition (pairwise tests), which allowed three main faunal groups along the depth gradient to be determined: 1) a group at the shallowest depths, $1.3 \mathrm{~m}$ to $7.2 \mathrm{~m}$ depth - stations $100 \mathrm{~m}$ to $500 \mathrm{~m}$ offshore ( 2 sub-groups were also formed from $1.3 \mathrm{~m}$ to $3.4 \mathrm{~m}$ and $4.4 \mathrm{~m}$ to 7.1 

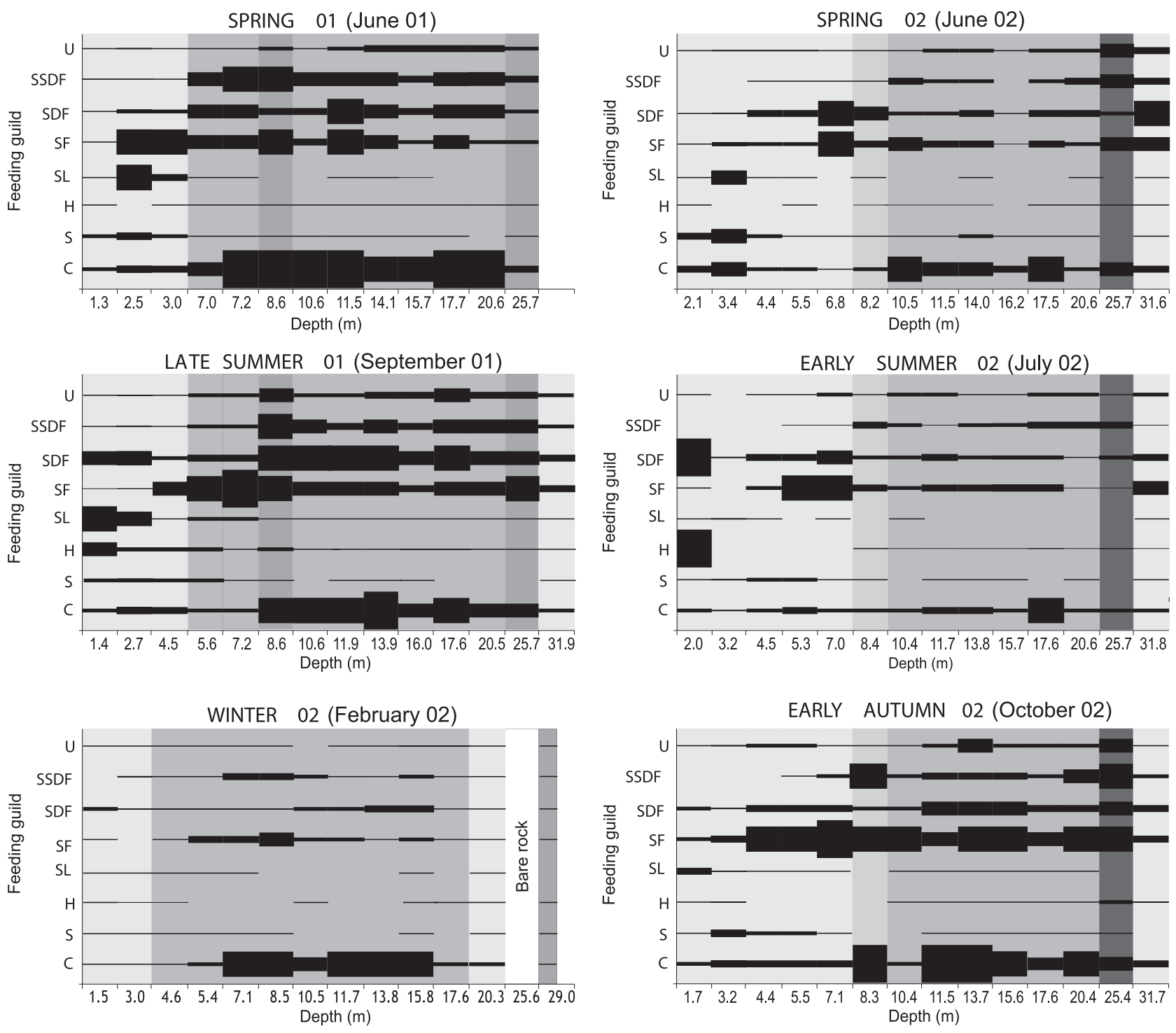

EARLY AUTUMN 02 (October 02)

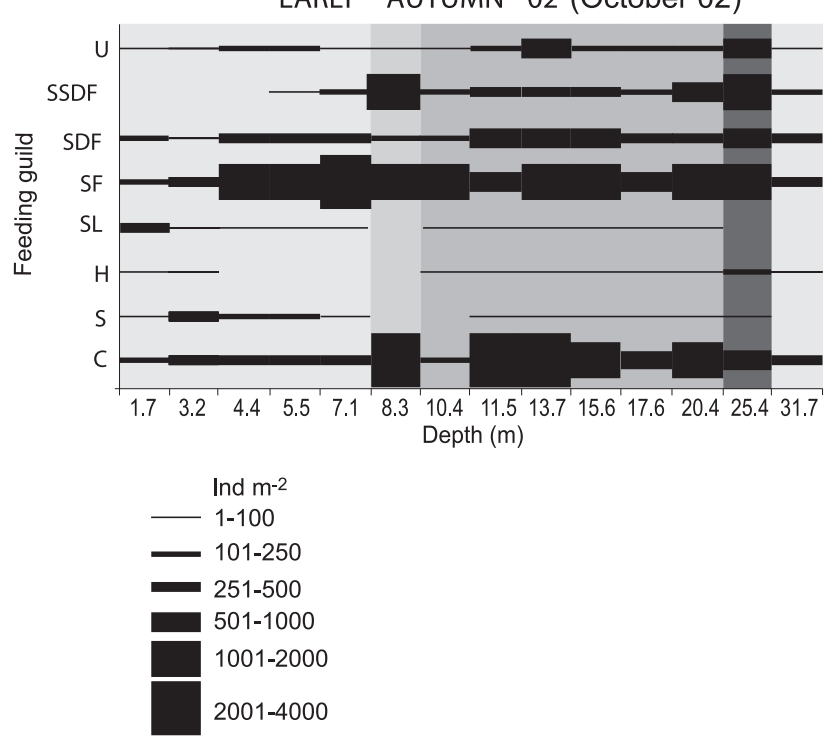

FIG. 4. - Density of the different trophic guild groups along the depth gradient, for the different seasons; grain size variations are indicated. Feeding guilds: C, carnivores; H, herbivores; S, scavengers; SDF, surface-deposit feeders; SF, suspension feeders; SL, sand-lickers; SSDF, subsurface-deposit feeders;; U, unknown; Grain Size: FS, fine sand; MS, medium sand; CS, coarse sand; VCS, very coarse sand; G, gravel.

$\mathrm{m})$; 2) a group from $8.2 \mathrm{~m}$ to $25.8 \mathrm{~m}$ depth, which corresponded to the sampling stations from $600 \mathrm{~m}$ to $4000 \mathrm{~m}$ offshore; and 3 ) a group at $32 \mathrm{~m}$ depth, at the sampling station $5000 \mathrm{~m}$ offshore. With the feeding guild densities, there was no clear evidence of group formation along the depth gradient. Samples at the shallowest areas clustered, as the pairwise tests showed that samples 100, 200 and 300 were not significantly different from each other, but they were significantly different from the remaining samples.

The faunal groups detected from the pairwise tests were represented on the MDS plots and the differences regarding the formation of different groups with depth were clarified (Fig. 5). The formation of different faunal groups was clear for the species composition (Fig. 5A), but not clear for the feeding guilds (Fig. 5B), as the dominance of a certain feeding guild gradually changed with depth. The feeding 

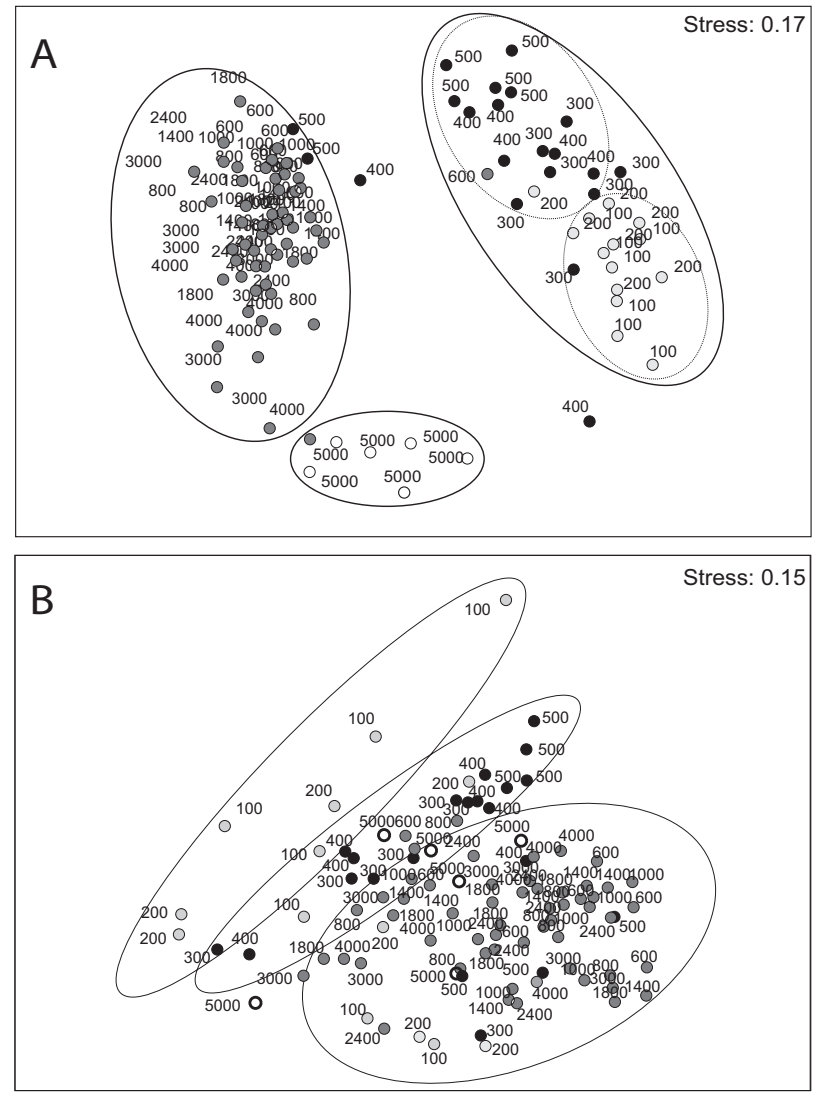

O $100-200$ (1.3 to $3.4 \mathrm{~m}$ depth) $\quad 300-500$ (4.2 to $7.1 \mathrm{~m}$ depth)

600 - 4000 (8.2 to $25.8 \mathrm{~m}$ depth) 05000 (31.8 $0.2 \mathrm{~m}$ depth)

FIG. 5. - MDS ordination plot of the macrobenthic community for the A) species densities and the B) feeding guild densities.

guilds that contributed most to the similarity of each station were determined with the SIMPER analysis (Table 3). C, S, SDF and SL contributed with the highest percentage of similarity at the shallowest areas, and S and SL were discriminated only in these areas (Table 3). SF became more abundant below $4 \mathrm{~m}$, especially between 6 and $8 \mathrm{~m}$ depth (Table 3 ), in agreement with the distribution of several SF bivalves (Table 2). C contributed to the similarity at all stations, but the highest percentages were observed between $8 \mathrm{~m}$ and $21 \mathrm{~m}$ depth (Table 3), which agrees with the distribution of the most abundant carnivores, mainly polychaetes and nemerteans (Table 2). SDF also contributed to the similarity of almost all stations of the depth gradient, but were more discriminated at intermediate depths (14 $\mathrm{m}$ and $16 \mathrm{~m}$ depth) and at the deepest sampling station, at $32 \mathrm{~m}$ depth (Table 3). SSDF were highly abundant at $8 \mathrm{~m}$ depth, but were discriminated more at deeper areas, $21 \mathrm{~m}$ and $26 \mathrm{~m}$ depth (Table 3). $\mathrm{H}$ were not discriminated at any depth/sampling station.

\section{Relation between feeding guild densities and environmental parameters}

The environmental parameters that most influence the distribution of the feeding guild densities in relation to the depth were analysed with RDA, for spring/ summer 01 and 02, winter 02 and autumn 02 (Fig. 6). All environmental variables (different percentages of grain sizes, oxygen, nitrate, nitrite, ammonia, phosphate, chlorophyll $a$, temperature) were used in a first analysis. A second RDA was run after collinear environmental variables were removed and the significant variables were selected with the forward selection procedure (Fig. 6). Total variance explained by the biotic data and environmental data was $85 \%$ for spring and summer 01, $61 \%$ for winter $02,58 \%$ for spring and summer 02 , and $86 \%$ for autumn 02 .

TABLE 3. - SIMPER analysis applied to the feeding guild densities per sampling station (mean depth \pm standard deviation), with indication of: the percentage of each station's mean similarity; and density (Ind $\mathrm{m}^{-2}$ ) and the percentage that each feeding guild (between brackets) contributed to the similarity of each sampling station.

\begin{tabular}{|c|c|c|c|c|c|c|c|c|}
\hline Station & $\begin{array}{l}\text { Mean depth } \\
\pm \text { standard } \\
\text { deviation }(\mathrm{m})\end{array}$ & $\begin{array}{l}\text { Mean } \\
\text { similarity } \\
(\%)\end{array}$ & $\begin{array}{l}\text { Carnivores } \\
\left(\text { Ind } \mathrm{m}^{-2}, \%\right)\end{array}$ & $\begin{array}{l}\text { Scavengers } \\
\left(\text { Ind } \mathrm{m}^{-2}, \%\right)\end{array}$ & $\begin{array}{l}\text { Sand-lickers } \\
\left(\text { Ind } \mathrm{m}^{-2}, \%\right)\end{array}$ & $\begin{array}{l}\text { Sub-surface- } \\
\text { deposit feeders } \\
\text { (Ind } \mathrm{m}^{-2}, \% \text { ) }\end{array}$ & $\begin{array}{c}\text { Surface-deposit } \\
\text { feeders } \\
\left.\text { (Ind } \mathrm{m}^{-2}, \%\right)\end{array}$ & $\begin{array}{c}\text { Suspension } \\
\text { feeders } \\
\left(\text { Ind } \mathrm{m}^{-2}, \%\right)\end{array}$ \\
\hline 100 & $-1.6 \pm 0.3$ & 32 & $280(32 \%)$ & $178(24 \%)$ & $283(12 \%)$ & & $567(18 \%)$ & $67(9 \%)$ \\
\hline 200 & $-3.0 \pm 0.3$ & 41 & $427(15 \%)$ & $270(31 \%)$ & $371(18 \%)$ & & $107(9 \%)$ & \\
\hline 300 & $-4.3 \pm 0.6$ & 45 & $353(30 \%)$ & $163(19 \%)$ & & & $198(9 \%)$ & $528(27 \%)$ \\
\hline 400 & $-5.8 \pm 0.6$ & 45 & $292(27 \%)$ & $91(7 \%)$ & & & $270(17 \%)$ & $936(45 \%)$ \\
\hline 500 & $-7.1 \pm 0.1$ & 42 & $999(24 \%)$ & & & & $450(17 \%)$ & $1394(50 \%)$ \\
\hline 600 & $-8.5 \pm 0.2$ & 48 & $2028(41 \%)$ & & & $705(19 \%)$ & & $884(32 \%)$ \\
\hline 800 & $-10.5 \pm 0.1$ & 50 & $1525(50 \%)$ & & & $338(16 \%)$ & $331(14 \%)$ & $502(21 \%)$ \\
\hline 1000 & $-11.6 \pm 0.2$ & 55 & $2060(59 \%)$ & & & & $718(17 \%)$ & $582(16 \%)$ \\
\hline 1400 & $-13.9 \pm 0.1$ & 50 & $2109(54 \%)$ & & & $291(10 \%)$ & $689(20 \%)$ & $516(14 \%)$ \\
\hline 1800 & $-15.8 \pm 0.2$ & 50 & $1339(49 \%)$ & & & $273(13 \%)$ & $388(19 \%)$ & $355(17 \%)$ \\
\hline 2400 & $-17.6 \pm 0.2$ & 56 & $1302(59 \%)$ & & & & $461(14 \%)$ & $433(17 \%)$ \\
\hline 3000 & $-20.5 \pm 0.1$ & 44 & $1182(38 \%)$ & & & $454(31 \%)$ & $248(13 \%)$ & $340(14 \%)$ \\
\hline 4000 & $-25.7 \pm 0.1$ & 54 & $826(35 \%)$ & & & $638(32 \%)$ & $338(13 \%)$ & $621(17 \%)$ \\
\hline 5000 & $-31.8 \pm 0.2$ & 50 & $363(23 \%)$ & & & $168(14 \%)$ & $443(27 \%)$ & $447(34 \%)$ \\
\hline
\end{tabular}



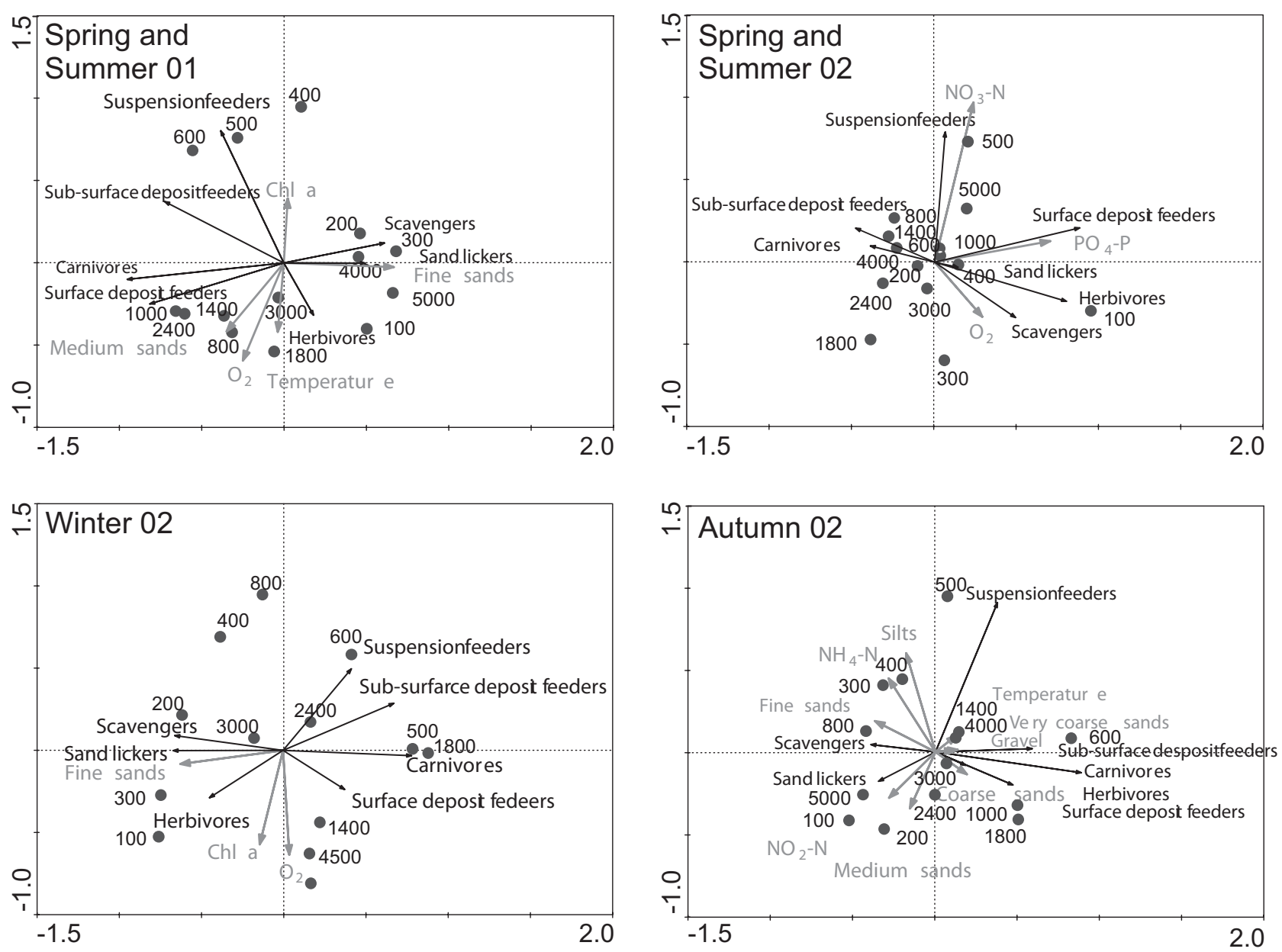

FIG. 6. - RDA ordination triplot for the feeding guilds. Circles, station positions within the ordination space; black vector lines, feeding guild density; grey vector lines, the relationship of the significant environmental variables to the ordination axis; the line's length is proportional to its relative significance.

The results showed that $\mathrm{C}$ and SSDF occurred in similar areas, and were more correlated with the presence of medium to coarse sands and gravel, especially in spring/summer 01 and autumn 02 , and not with fine sands (Fig. 6). SF were distributed in different areas to all the other feeding guilds, except in winter 02, when they were associated with SSDF (Fig. 6). SF were generally associated with shallow depths (7 m depth, Table 3 ), with higher concentrations of chlorophyll $a$ in spring/summer 01, higher concentrations of $\mathrm{NO}_{3}-\mathrm{N}$ in spring and summer 02 , and with temperature (lower temperatures in spring/ summer 01 and higher in autumn 02) (Fig. 6).

SDF were associated more with areas with coarser sands, higher concentrations of $\mathrm{PO}_{4}-\mathrm{P}$ in spring/ summer 02 , and higher oxygen concentrations in spring/summer 01 (Fig. 6). SL, H and S occurred in similar areas and were mainly associated with the shallowest depths, with fine sands (spring/summer 01, autumn 02), a higher concentration of chlorophyll $a$ in spring/summer 01, and higher concentrations of oxygen in spring/summer 01 and 02 (Fig. 6)

\section{DISCUSSION}

\section{Spatial differences in the feeding guild composition}

Clear spatial differences in the macrobenthic community composition related to the hydrodynamics and morphodynamics were detected along the studied depth gradient (Dolbeth et al., 2007). Areas with different characteristic fauna were observed with a clear separation between the shallow depths, subjected to hydrodynamics acting on the seabottom (7.2 $\mathrm{m}$ depth shorewards), and the deeper areas, with no significant wave energy impact at the seabottom (from 8.4 m seawards) (Dolbeth et al., 2007). The present study also showed spatial differences in the 
feeding guild composition of the macrobenthic community along the depth gradient, but no clear spatial groups of feeding guilds were formed as observed with the species composition. Instead, there was a gradual change in the dominance of a feeding guild, which was also related to the higher or lower impact of the hydrodynamics on the seafloor.

At the shallowest depths of the gradient (1-3 m depth), at the areas continuously subjected to high environmental stress (Dolbeth et al., 2007), the dominant feeding guilds were mainly sand-lickers (SL), herbivores $(\mathrm{H})$ and scavengers $(\mathrm{S})$. These feeding guilds were made up of only a few species, mainly hermit crabs and amphipods. These suprabenthic crustaceans were also found in high abundances between the swash (not sampled in the study) and surf zones in other studies (San Vicente and Sorbe, 1999; Tirelli et al., 2000; Connor et al., 2004) and have been considered important for nutrient regeneration (San Vicente and Sorbe, 1999). However, the present results did not show a clear association between these feeding guilds and the nutrient concentrations, except for phosphates in spring/summer 02 and nitrites in autumn 02. The distribution of these feeding guilds in shallow, environmentally-stressed areas is related to the feeding strategies of $\mathrm{H}$ and SL which rely on primary production, and also on the lower predation impact, as seen for the scavenger Diogenes pugilator (Tirelli et al., 2000). Correlations were only found between H, SL and chlorophyll $a$ (a proxy of phytoplankton production, Wieking and Kröncke, 2005) in the winter, but phytobenthos (not assessed in this study) is also an important resource in these shallow areas (Urban-Malinga and Wiktor, 2003). In fact, SL feeding strategies consist in cleaning food particles of the sand grains, mostly microphytobenthos (Wieking and Kröncke, 2003, 2005) with higher production at shallow areas (Urban-Malinga and Wiktor, 2003). H, SL and S were also associated with higher concentrations of dissolved oxygen. For most of the study period and depth gradient, the oxygen levels were within high quality standards under water framework directive objectives, which set 5.7 $\mathrm{mg} \mathrm{L}^{-1}$ to $7 \mathrm{mg} \mathrm{L}^{-1}$ (respectively for the marine and freshwater limits) as the limits above which most biological requirements are satisfied (Best et al., 2007). Therefore, oxygen should not be an impairing factor for any of the feeding guilds in the study.

Suspension feeder (SF) communities are generally associated to areas with strong hydrodynamics acting on the seafloor (Rosenberg, 1995; Wildish and
Kristmanson, 1997; Gili and Coma, 1998; Muniz and Pires, 1999). This is related to their dependence on higher oxygen concentrations and the need for small re-suspended particles for feeding purposes (Rosenberg, 1995; Gili and Coma, 1998; Muniz and Pires, 1999). In agreement with this, SF were distributed further offshore (4-12 m depth), but still in areas subjected to a hydrodynamic impact on the seafloor, as the depth of closure varied between 2.3 $\mathrm{m}$ and $10 \mathrm{~m}$ depth (Dolbeth et al., 2007). In addition, SF were associated with coarser sand areas and were correlated with higher concentrations of chlorophyll $a$, which indicates that phytoplankton production may be an important food resource. SF were mainly bivalves, such as Tellina spp. and the commercially harvested Spisula solida and Donax spp. (Gaspar et al., 1999a, b; Chícharo et al., 2002a). The depth distribution of these bivalves and this feeding guild agreed with other studies (Gaspar et al., 1999a, b; Wieking and Kröncke, 2003; Hoey et al., 2004).

Surface deposit feeders (SDF) are generally associated with areas with little hydrodynamic action on the seafloor, as currents limit their feeding and locomotion abilities (Wildish and Kristmanson, 1997). In the present study, SDF were distributed with higher densities in deeper areas that correlated with coarser sands, but they also appeared in the shallower areas. SDF were also quite abundant in the deepest areas with silts to fine sands, which is similar to the findings of Gaudêncio and Cabral (2007). Several species may change their feeding type in response to flow and food flux conditions (Snelgrove and Butman, 1994, Gaudêncio and Cabral, 2007), as seen for spionid worms, such as Prionospio spp. (Gaston, 1987), and for the amphipod Siphonoecetes sp. (Sprung, 1994). These species were distributed in the shallow areas and were classified as SDF-SF and SDF-H; however, it is possible that individuals have a single feeding behaviour according to the hydrodynamics.

Following the depth gradient, an abundant polychaete community was distributed in areas below the depth of closure and therefore with no significant wave climate impact on the seafloor (from $8 \mathrm{~m}$ depth offshore) (Dolbeth et al., 2007). Similar key species and groups were also observed in other coastal areas below 8 m depth (Sardá et al., 1999; Desroy et al., 2002; Wieking and Kröncke, 2003; Hoey et al., 2004). Most of these polychaetes were carnivores and were distributed in coarser sands, which was also found by Gaston (1987). Their presence, coexisting with 
other functional feeding guilds, is assumed to take an important and structuring role in the community (Wieking and Kröncke, 2003, 2005; Levinton and Kelaher, 2004). However, for the present study it is important to consider that results refer to the density dominance and most of the main carnivores found were small polychaetes, such as $P$. remota and $G$. galaica, and nemerteans. It has been argued that the distribution of these carnivore polychaetes in coarser sands is associated with a greater mobility of the interstitial organisms that the polychaetes feed on and to higher oxygen penetration (Gaston, 1987).

The depth of the sediment in which individual feeds on determines which feeding guild is found, as SDF prefer to feed directly on newly deposited organic matter, while sub-surface deposit feeders (SSDF) primarily feed on older organic matter (Rosenberg, 1995; Muniz and Pires, 1999; Byrén et al., 2002). SSDF are often associated with areas with no significant hydrodynamics impact and high organic matter sediments (Rosenberg, 1995; Muniz and Pires, 1999). Accordingly, this guild was more abundant in the deepest areas, below $18 \mathrm{~m}$ depth, where wave energy is never felt (Dolbeth et al., 2007), in line with the results of Wieking and Kröncke (2003) for Dogger Bank. In fact, relict and biogenic sediments where SSDF were abundant were only found at $26 \mathrm{~m}$ depth, which is evidence of the low hydrodynamics acting on the seafloor. Although relict sediments are not in equilibrium with the low-energy conditions, they consist of particles supplied to the shelf before the present time and under different conditions ( $\mathrm{Pi}$ net, 2003). At $32 \mathrm{~m}$ depth, there were fine sands and silts. Although, no information is available on the organic content of these sediments, mud deposits were observed at both $26 \mathrm{~m}$ and $32 \mathrm{~m}$ depth (personal observation) with a higher organic content, which favours SSDF occurrence (Mancinelli et al., 1998; Gaudêncio and Cabral, 2007). This analogy between decreasing wave exposure and higher accumulations of organic matter has been observed for the intertidal beach environment (Incera et al., 2003).

\section{Seasonal differences}

The numerical dominance of one feeding guild in the community changed seasonally. In general, in winter and spring $\mathrm{C}$ dominated, while in summer SF and SDF dominated the community. The numerically dominance of $\mathrm{C}$ contrasts with other studies for the coastal shelf (Gaudêncio and Cabral, 2007; Laudien et al., 2007) and other ecosystems, such as estuaries (Sprung, 1994; Cardoso et al., 2004; Levinton and Kelaher, 2004), and littoral rocky shores (Gili and Coma, 1998; Boaventura et al., 1999), where SDF and SF dominated. However, the present study also concluded that SDF and SF dominated in the summer. It has even been argued that the dominance of predation could be a result of arbitrary development that follows environmental or anthropogenic disturbance (Roth and Wilson, 1998). Most of the $\mathrm{C}$ dominance occurred in the periods of the year that followed the highest physical disturbances at the seafloor, i.e., winter (4 storms, depth of closure of $10 \mathrm{~m}$ ) and after the winter periods, especially spring 02, when 3 storms occurred and the depth of closure was $6.6 \mathrm{~m}$ between February and June 02 (Dolbeth et al., 2007). These results contrast with the results of Levin and DiBacco (1995), who found SSDF to be the dominant initial colonisers (7-week) after disturbance events. $\mathrm{C}$ were more abundant at depths not subjected to wave climate impact (from $8 \mathrm{~m}$ depth seawards, Dolbeth et al., 2007), which can explain, in part, their dominance following the largest disturbance events, as they were not subjected to severe physical stress as were, for example, SF. Another aspect that might be important is the bivalve fishery that takes place on the south coast of Portugal, essentially between 7 and $10 \mathrm{~m}$ depth (Chícharo et al., 2002a, b, 2003; Gaspar et al., 1999a, b, 2002), mainly in spring and summer, that catch clams with the minimum legal landing length (Dolbeth et al., 2006). Previous studies showed that seafloor disturbance due to dredging led to an increase in the density of potential predators, especially scavengers, distributed around 7 to $10 \mathrm{~m}$ depth, as this depth provides more feeding alternatives, such as the injured macrofauna (Chícharo et al., 2002b, 2003).

\section{CONCLUSIONS}

The feeding guild composition of the macrobenthic community seems to reflect the hydrodynamics impact on the seafloor. However, the changes in the feeding guild dominances were gradual, in opposition to the clear spatial differences observed for the species composition. $\mathrm{H}$ and SL dominated at the shallowest depths, which agree with their correlations with higher levels of primary production. $\mathrm{S}$ was also distributed in the shallow areas, which is associated with the lower predation impact on the main scavenger species. SF 
followed the gradient in areas with coarser sands and higher primary production, and also in areas subjected to a physical impact, in agreement with their need for small re-suspended particles for feeding purposes. C, SDF and SSDF were distributed mainly at depths below which no significant impact from wave climate occurred. $\mathrm{C}$ were associated with coarser sands and were mainly small polychaetes and nemerteans. SSDF were more abundant in areas with fine sands and mud deposits located at the deepest areas of the depth gradient and with higher organic content, in agreement with their feeding requirements. SDF could also occur at shallower depths, as they prefer newly deposited organic matter. $\mathrm{C}$ were numerically abundant in winter and spring, which, although not conclusively, was associated with environmental and anthropogenic impacts.

\section{ACKNOWLEDGEMENTS}

The authors are indebted to Filipe Martinho, João Neto, Adriano Miguel and Daniel Pires who participated in the field work, to João Pedro Cascalho for determining sediment grain size and to the CIACOMAR team for the hydrographical data. This work was supported by the CROP project (PDCTM/P/MAR/15265/1999).

\section{REFERENCES}

Arruda, E.P., O. Domaneschi and A.C.Z. Amaral. - 2003. Mollusc feeding guilds on sandy beaches in São Paulo State, Brazil. Mar. Biol., 143: 691-701.

Best, M.A, A.W. Wither and S. Coates. - 2007. Dissolved oxygen as a physico-chemical supporting element in the Water Framework Directive. Mar. Poll. Bull., 55: 53-64.

Byrén, L., G. Ejdung and R. Elmgren. - 2002. Comparing rate and depth of feeding in benthic deposit-feeders: a test on two amphipods, Monoporeia affinis (Lindström) and Pontoporeia femorata Kröyer. J. Exp. Mar. Biol. Ecol., 281: 109-121.

Boaventura, D., L.C. Fonseca and C. Teles-Ferreira. - 1999. Trophic structure of macrobenthic communities on the Portuguese coast. A review of lagonal, estuarine and rocky littoral habitats. Acta Oecol., 20(4): 407-415.

Cardoso, P.G., M.A. Pardal, A.I. Lillebø, S.M. Ferreira, D. Raffaelli and J.C. Marques. - 2004. Dynamic changes in seagrass assemblages under eutrophication and implications for recovery. $J$. Exp. Mar. Biol. Ecol., 302: 233-248.

Chícharo, L., J. Regala, M. Gaspar, F. Alves and M.A. Chícharo. - 2002a. Macrofauna spatial differences within clam dredgetracks and their implications for short-term fishing effects studies. Fish. Res., 54: 349-353.

Chícharo, L., M.A. Chícharo, M.Gaspar, J. Regala and F. Alves. $-2002 \mathrm{~b}$. Reburial time and indirect mortality of Spisula solida clams caused by dredging. Fish. Res., 59: 247-257.

Chícharo, M.A., L. Chícharo, A. Amaral, S. Condinho and M. Gaspar. - 2003. Chronic effects of dredging-induced stress on the clam (Spisula solida): nucleic acid and lipid composition. Fish. Res., 63: 447-452
Connor, D.W., H. Allen, N. Golding, K.L. Howell, L.M. Lieberknecht, K.O. Northen, and J.B. Reker. - 2004. The Marine Habitat Classification for Britain and Ireland Version 04.05 JNCC, Peterborough ISBN 1861075618 [internet version]. Available from www.jncc.gov.uk/MarineHabitatClassification [cited 22 February 2005].

Costa, M., R. Silva and J. Vitorino. - 2001. Contribuição para o estudo do clima de agitação marítima na costa portuguesa.

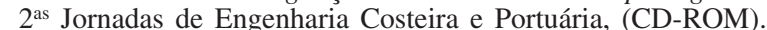
Laboratório Nacional de Engenharia Civil, Lisbon.

Desroy, N., C. Warembourg, J.M. Dewarumez and J.C. Dauvin. - 2002. Macrobenthic resources of the shallow soft-bottom sediments in the eastern English Channel and southern North Sea. ICES J. Mar. Sci., 60: 120-131.

Dolbeth, M., I. Viegas, F. Martinho, J.C. Marques and M.A. Pardal. - 2006. Population structure and species dynamics of Spisula solida, Diogenes pugilator and Branchiostoma lanceolatum along a temporal-spatial gradient in the south coast of Portugal. Estuar. Coast. Shelf Sci., 66: 168-176.

Dolbeth, M., Ó. Ferreira, H. Teixeira, J.C. Marques, J.A. Dias and M.A. Pardal. - 2007. Beach morphodynamics impact on a macrobenthic community along a subtidal depth gradient. Mar. Ecol. Prog. Ser., 352: 113-124.

Fauchald, K. and P.A. Jumars. - 1979. The diet of worms: a study of polychaete feeding guilds. Oceanogr. Mar. Biol. Ann. Rev., 17: 193-284.

Ferreira, Ó., J.C. Martins and J.A. Dias. - 1997. Morfodinâmica e vulnerabilidade da Praia de Faro, pp. 67-76. Seminário sobre a Zona Costeira do Algarve, Faro.

Gaspar, M.B., R. Ferreira and C.C. Monteiro. - 1999a. Growth and reproductive cycle of Donax trunculus L., (Mollusca: Bivalvia) off Faro, southern Portugal. Fish. Res., 41: 309-316.

Gaspar, M.B., M. Castro and C.C. Monteiro. - 1999b. Effect of tooth spacing and mesh size on the catch of the Portuguese clam and razor clam dredge. ICES J. Mar. Sci., 56: 103-110.

Gaspar, M.B., L. Leitão, M.N. Santos, M. Sobral, L. Chícharo, A. Chícharo and C.C. Monteiro. - 2002. Influence of mesh size and tooth spacing on the proportion of damaged organisms in the catches of the Portuguese clam dredge fishery. ICES J. Mar. Sci., 59: 1228-1236.

Gaston, G.R. - 1987. Benthic Polychaeta of the Middle Atlantic Bight: feeding and distribution. Mar. Ecol. Prog. Ser., 36: 251-262.

Gaudêncio, M.J. and H.N. Cabral. - 2007. Trophic structure of macrobenthos in the Tagus estuary and adjacent coastal shelf. Hydrobiologia, 587: 241-251.

Gili, J.M. and R. Coma. - 1998. Benthic suspension feeders: their paramount role in littoral marine food webs. Trends Ecol. Evol., 13: 316-321.

Hewitt, J.E., V.J. Cummings, J.I. Ellisa, G. Funnella, A. Norkko, T.S. Talley and S.F. Thrush. -2003 . The role of waves in the colonisation of terrestrial sediments deposited in the marine environment. J. Exp. Mar. Biol. Ecol., 290: 19-47.

Hoey, V.G., S. Degraer and M. Vincx. - 2004. Macronbenthic community structure of the soft bottom sediments at the Belgian Continental Shelf. Estuar. Coast. Shelf Sci., 59: 599-613.

Incera, M., S.P. Cividanes, J. López and R. Costas. - 2003. Role of hydrodynamic conditions on quantity and biochemical composition of sediment organic matter in sandy intertidal sediments (NW Atlantic coast, Iberian Peninsula). Hydrobiologia, 497: $39-51$.

Laudien, J., M. Herrmann and W.E. Arntz. - 2007. Soft bottom species richness and diversity as a function of depth and iceberg scour in Arctic glacial Kongsfjorden (Svalbard). Polar Biol., 30: 1035-1046.

Levin, L.A. and C. DiBacco. - 1995. Influence of sediment transport on short-term recolonization by seamount infauna. Mar. Ecol. Prog. Ser., 123: 163-175.

Levinton, J. and B. Kelaher. - 2004. Opposing organizing forces of deposit-feeding marine communities. J. Exp. Mar. Biol. Ecol., 300: $65-82$

Limnologisk Metodik. - 1992. Ferskvandsbiologisk Laboratorium. Københavns Universitet (Ed.), Akademisk Forlag, København.

Mancinelli, G., S. Fazi and L. Rossi. - 1998. Sediment structural properties mediating dominant feeding types patterns in softbottom macrobenthos of the Northern Adriatic Sea. Hydrobiologia, 367: 211-222. 
MarLin - Marine Life Information Network: Biology and Sensitivity Key Information Sub-programme [on-line]. Plymouth: Marine Biological Association of the United Kingdom. http://www. marlin.ac.uk/sah/species_information.php.

Morin, J.G., J.E. Kastendiek, A. Harrington and N.N. Davis - 1985. Organization and patterns of interactions in a subtidal sand community on an exposed coast. Mar. Ecol. Prog. Ser., 27: 163-185

Muniz, P. and A.M.S. Pires. - 1999. Trophic structure of the polychaetes in the São Sebastião Channel (southeastern Brazil). Mar. Biol., 134: 517-528.

Nicholls, R.J., W.A. Birkemeier and G. Lee. - 1998. Evaluation of depth of closure using data from Duck, NC, USA. Mar. Geol., 148: 179-201.

Oug, E., K. Næsm and B. Rygg. - 1998. Relationship between soft bottom Macrofauna and polycyclic aromatic hydrocarbons (PAH) from smelter discharge in Norwegian fjords and coastal waters. Mar. Ecol. Prog. Ser., 173: 39-52.

Parsons, T.R., Y. Maita and C.M. Lally. - 1985. Pigments. In: T.R. Parsons (ed.), A Manual of Chemical and Biological Methods for Seawater Analysis, pp. 101-104. Pergamon Press, Oxford.

Pinet, P.R. - 2003. Invitation to Oceanography (3rd ed.). Jones and Barlett publishers Canada, Mississauga.

Rosenberg, R. - 1995. Benthic marine fauna structured by hydrodynamic processes and food availability. Neth. J. Sea Res., 34: 303-317.

Roth, S. and J.G. Wilson. - 1998. Functional analysis by trophic guilds of macrobenthic community structure in Dublin Bay, Ireland. J. Exp. Mar. Biol. Ecol., 222: 195-217.

San Vicente, C. and J.C. Sorbe. - 1999. Spatio-temporal structure of the suprabenthic community from the Creixell beach (western Mediterranean). Acta Oecol., 20(4): 377-389.

Sardá, R., S. Pinedo and D. Martin. - 1999. Seasonal dynamics of macroinfaunal key species inhabiting shallow soft-bottoms in the Bay of Blanes (NW Mediterranean). Acta Oecol., 20(4):
315-326.

Sardá, R., S. Pinedo, A. Grémare and S. Taboada. - 2000. Changes in the dynamics of shallow sandy-bottom assemblages due to sand extraction in the Catalan Western Mediterranean Sea. ICES J. Mar. Sci., 57: 1446-1453.

Shepard, F.P. - 1954. Nomenclature based on sand-silt-clay ratios. J. Sediment. Petrol., 24: 151-158.

Snelgrove, P.V.R. and C.A. Butman. - 1994. Animal-sediment relationships revisited - cause versus effect. Oceanog. Mar. Biol., 32: $111-117$.

Sprung, M. - 1994. Macrobenthic secondary production in the intertidal zone of Ria Formosa-a lagoon in southern Portugal. Estuar. Coast. Shelf Sci., 38: 539-558.

Strickland, J.D.M. and T.R. Parsons. - 1972. A Practical Handbook of Seawater Analysis (2 ${ }^{\text {nd }}$ ed.). Fisheries Research Board of Canada, Ottawa.

Tirelli, T., M. Dappiano, G. Maiorana and P. Pessani. - 2000. Intraspecific relationship of the hermit crab Diogenes pugilator: predation and competition. Hydrobiologia, 439: 43-48.

Urban-Malinga, B. and J. Wiktor. - 2003. Microphytobenthic primary production along a non-tidal sandy beach gradient: an annual study from the Baltic Sea. Oceanologia, 45: 705-720.

Wieking, G. and I. Kröncke. - 2003. The Dogger Bank example Macrofauna communities of the Dogger Bank (central North Sea) in the late 1990s: spatial distribution, species composition and trophic structure. Helgol. Mar. Res., 57: 34-46.

Wieking, G. and I. Kröncke. - 2005. Is benthic trophic structure affected by food quality? The Dogger Bank example. Mar. Biol., 146: $387-400$

Wildish, D. and D. Kristmanson. - 1997. Benthic suspension feeders and flow. Cambridge University Press, USA.

Scient. ed.: W.E. Arntz.

Received December 10, 2007. Accepted July 24, 2008.

Published online March 2, 2009. 